\title{
On the dating of the three-parted temples of Anakopia and Nizhne-Arkhyz fortified settlement.
}

\author{
Victoria Pishchulina* and Evgenia Kishkinova \\ Don State Technical University, 344002, Rostov-on-Don, Russia
}

\begin{abstract}
The article is devoted to the architectural features comparative analysis of the medieval temples of Simon the Canaanite in New Athos (Abkhazia) and North Zelenchuksky in Karachay-Cherkessia (Russian Federation) in the context of three-porch temples, the study of prototypes of their architectural forms, and a description of the building solutions analysis results of the temples based on the X-ray phase method. This method is applied to the named temples' research for the first time. The scientific novelty of the article is due to the fact that a comprehensive study of the planning, volumetric-spatial solution and building material of the temples of Simon the Canaanite and Severny Zelenchuksky, based on the results of physical and chemical analysis, allows us to confirm their dating to the 10th century and establish the chronological proximity of the two monuments.
\end{abstract}

\section{Introduction}

Purpose of this article is substantiation using the physical and chemical method of the medieval temples' dating analysis of Simon the Canaanite and North Zelenchuksky.

Tasks: study of the architectural features of the Simon the Canaanite and the Northern Zelenchuk temple as cross-domed, three-parted; presentation of the results of physical and chemical analysis of building solutions of temples; temples' dating substantiation by the $\mathrm{X}$ century.

\footnotetext{
* Corresponding author: viktvlad@mail.ru
} 


\section{Main part}

Among the numerous medieval Christian temples of Abkhazia, researchers have long identified a fairly homogeneous group belonging to the type of "inscribed cross" and including such monuments as: the Pitsunda temple, temples in the village Lykhny, Simon the Canaanite in the city of New Athos, Inal-nyha (Bzybsky), Gech-nyha in the village Veseloe, Loo-nyha in the village Loo, the cathedral in the village Mokva. All of them (except for the five-nave and five-apse, which does not have a narthex of the Mokva Cathedral) are three-nave, three-apse, three-aisled, have narthexes and date back to the 9th11 th centuries. They are related to the North Zelenchuksky and Shoaninsky temples located on the territory of North Ossetia (the latter is devoid of a narthex and includes two, not three porches). Variations in the construction technique, the shape of the supports, the presence or absence of strict symmetry, the development of the west-eastern axis, which distinguish the monuments, cannot shake the undoubted similarity of the volumetric-spatial compositions, proportions and planning solutions of these temples. An extensive literature is devoted to the listed monuments, while the question of a single prototype, chronological sequence of objects and the genesis of the vestibules adjacent to the main volume remains open. The lack of consensus regarding the dating of temples, especially given the presence of often several construction periods, makes it difficult to find prototypes and determine the vector of influence within the group itself. In this regard, it seems advisable to use physical and chemical research methods, in particular, the experimental technology using X-ray phase analysis, for the study of lime solutions from different parts of the temples.

So, the temple of Simon the Canaanite in historical Anakopia (now New Athos) A.S. Bashkirov dates the X-XI centuries [4], L. D. Rcheulishvili [14], L, G. Khrushkova [16], Z. V. Anchabadze [2] and Yu. N. Voronov [7] - at the end of the 9th - 10th centuries, V. S Patchulia [10] - X - XIII centuries. According to the results of X-ray phase analysis, the vestibule is dated to the end of the 9th century, the altar part - to the end of the 10th century.

Church of St. Simon the Canaanite is a cross-domed one and, as already mentioned, belongs to the type of an inscribed cross. The interior decoration, as in the Northern Zelenchuk temple, included fresco painting, the analysis of which is beyond the scope of this article. The dimensions according to D.K. Chachkhalia measurements are: length 19, $29 \mathrm{~m}$; width $10.4 \mathrm{~m}$. [17]. The temple includes three apses, the central of which is wider than the lateral ones, further extended and has a pentahedral shape from the outside. The side apses are semicircular on the outside, and inside all three are horseshoe-shaped, with the central one cut through by five windows, and the side ones include one window each. There is bema there. The pre-altar pillars are smaller in cross-section than the dome pillars, which have a cross-sectional shape. The eastern pair of dome pillars is more massive than the western one. The pilasters of the walls are aligned with the pillars. There are two more pilasters on the western wall facing the naos, which also coincide along the axes with the pillars. The north and south entrances are located opposite each other. The southern wall is 
cut by two windows. The narthex, which is lowered relative to the naos, adjoins from the west. It also has pilasters on the west wall, two windows on the west wall, and three entrances from the west, north and south. On three sides of the temple adjoined the vestibules, now lost. The drum rests on the four aforementioned cross pillars, the midsection is raised. Above each doorway there is an architrave beam and a semicircular tympanum. The masonry is made of limestone of good crandall, with a clear coincidence of horizontal rows, with moellon. The temple has been preserved up to the level of the supporting arches, then - the result of restoration. The temple was restored in the second half of the 19th century, the last restoration, which was very successful according to Rcheulishvili was carried out in 1956 [14]. There was no choir in the temple. D.K. Chachkhalia believes that initially there could have been no narthex either. "The southern and northern doorways of the temple of Simon the Canaanite are not in the center of the transverse nave and sub-dome space, but along the sub-dome pillars western pair eastern side line. There are also southern and northern doors in the Lykh-nykh temple and the Northern temple of Arkhyz". [17, p. 24].

The horseshoe shape of the inner part of the apses finds numerous prototypes in the architecture of Transcaucasia and Cappadocia. In particular, the temples in Kasakh (IV-V centuries, Armenia) have a horseshoe-shaped apse from the inside and a pentahedral apse on the outside; in Vachnadziani (border of the 8th and 9th centuries, Georgia); horseshoeshaped apse of the church of St. John the Baptist in Chavushin (5th century, Cappadocia, now Turkey), and Durmush-Kadyr-kilisesi in Avcilar (beginning of the 6th century, now Turkey). These are just a few examples. As for the cross-shaped pillars, A. Yu. Vinogradov and Beletsky indicate their use in the Eastern Pontic region, along with Abkhazia - in Chersonesos (temple No. 31) and Trebizond (St. Anna's temple at the end of the 9th century), and later in Ancient Russia. As these authors note, the temples of Trebizond at the turn of the 9th-10th centuries have such elements as "pure masonry and wall cladding and plinth masonry of arches and vaults, undivided outer walls and profiled basements, a combination of faceted central and semicircular lateral apses, highlighted girder arches, raised bema...", which indicates their relationship "with the temples of the "Abkhazian" school" [6, p. 205].

The situation with the search for prototypes of the porches is more complicated. They are very common in later monuments, and from the synchronous Abkhaz ones they are found again only in the temples of Trebizond $[9,11,13]$. So, the vestibules on the northern facades have the Trebizond churches of St. Eugenia (X - XIV centuries) and Chrysokephalos (X century), however, the vestibules themselves are dated here, respectively, in the XIII and XIII - XIV centuries. Church of St. Sophia in Trebizond is complicated by three porches dating back to the end of the 12th - 13th centuries. Thus, as D.K. Chachkhalia emphasizes, the Trebizond examples also chronologically follow the Abkhaz ones, and do not precede them [17], therefore, the developed three-part composition is autochthonous Abkhazian. However, this does not exclude some kind of "push" that entailed the new element formation. 
The appearance of the vestibules in the three-dimensional compositions of Abkhaz churches may be associated, firstly, with the imitation of a certain authoritative model - a temple that has not come down to us at all or that has survived fragmentarily and has not yet been studied. Secondly, their appearance could be due to the local characteristics of worship. Thirdly, the architectural form that came from non-church architecture residential, serf, etc., could become an impulse for the formation of the vestibules. Finally, fourthly, architectural elements that resemble vestibules, but are not, could serve as a prototype. In particular, portals characteristic of the temple architecture of Armenia could act as such prototypes.

The portals of Armenian temples are numerous, varied in decor - architectural and sculptural - and are not the same in terms of preservation. As a rule, they have a gable roof and arched openings resting on columns, pairs of columns, wall ends. These are the portals of the temple in Kasakh (IV century), the Ereruik basilica of the 5th century, the Avan temple and the temple of St. Gregory in Aruch, VI century, temples in Ptgnavanka, VI-VII centuries, St. Gayane in Etchmiadzin, VII century. A cautious assumption can be made that it was precisely these plastic-expressive elements that served as the basis for the Abkhaz temples' open vestibules formation.

The Northern Zelenchuksky temple in the territory of Karachay-Cherkessia (RF) is marked by an undoubted similarity with the above-named group of temples. It is also crossdomed and belongs to the type of inscribed cross. The monument has been studied in detail by V.A. Kuznetsov. According to Kuznetsov, the monument is $25.5 \mathrm{~m}$ long and $19.5 \mathrm{~m}$ wide with porches [8]. The main space is rectangular in plan, stretched from west to east and is completed with three apses, semicircular outside and inside, while the central one is longer and wider than the side ones, cut through by three windows and complemented by a three-stage synthronon. Similar synthronons are found in the Mokvi temple (mid-10th century) and the Pitsunda Cathedral. Along the line of the altar pillars, there is salt; in the southern nave below it, a burial in a stone box was found. This suggests the presence of a throne in the southern apse [5]. The north nave does not include salt. The side apses have one window each. The apses are interconnected by arched passages in the bema, between the eastern pairs of pre-altar and sub-dome pillars. The side apses have hangers on the outer walls. The dome pillars are larger than the pre-altar ones; in cross-section they are rectangular, with somewhat uneven outlines. The pilasters of the walls are narrower than the dome pillars and do not completely coincide with them along the axes; as a result, the supporting arches rest on the "shelves" of the pillars. The wall separating the narthex is cut by three wide openings and forms L-shaped segments in the plan, which can be considered as another pair of pillars. The western corners of the main space are complicated by corner pilasters. From the south and north there are vestibules, and the opening to the north is narrower than to the south. There are three entrances to the narthex - from the north, from the south and from the west, through the narthex, which has an additional entrance from the south. The transverse walls of the narthex are complicated by pilasters of the main entrance sides. The side porches have niches rounded in plan in the eastern walls. The masonry of 
the arches is a brick on a thick layer of mortar. The walls and the dome are made of hewn squares and slabs of sandstone on lime mortar [8]. In the corners, the masonry is made with alternating squares. The cylindrical drum is cut through by eight windows; a curb belt of plinth runs under the cornice. The dome has a hemispherical shape from the inside with two key stones, from the outside it is conical. The vaults are corrugated. All openings have arched shapes, while all doorways are complicated by lunettes above the horizontal lintels. There are two window openings in the side naves, and four in the transept, which, together with the drum windows, provides good illumination of the dome space. Chachkhalia suggests that the narthex with the western vestibule did not appear at the same time as the temple, but were added a little later. In the northwestern corner of the narthex, the remains of a baptismal room, probably later, and stairs to the choir are discovered. A later addition with burials is located between the narthex and the southern vestibule. The basement of the church itself is three-staged; the vestibules are two-staged. V.A. Kuznetsov, who studied the temple in detail, noted its significant similarity with the Lykhny temple, considered it to be built simultaneously with it and dated it to the 10th century. An important dating artifact is an inscription on a narthex cross containing a mention of 1067, this is the upper limit of the dating of a temple that was clearly built earlier. At the same time, Kuznetsov tends to date the monument to the second quarter of the 10th century, linking it with the construction activities of the Abkhazian Tsar George II and considering it the cathedral of the Alan Diocese [8, p. 148]. Vinogradov and Beletsky, giving the role of the cathedral to the Middle Zelenchuk temple, supplemented Kuznetsov's detailed description of the Northern one. In particular, they drew attention to the fact that its domed arches are threestaged, the corrugated arches of the arms of the cross are oriented from the center, and the arches of the corner compartments are longitudinal. The narthex was two-tiered, with choir openings in the naos with a wide opening, which is unique for Alanya. These authors date the temple to the end of the $\mathrm{X}$ century, considering it to be a simplified version of the temples of Lykhny, New Athos, Alakhadza [5, p. 293]. L.A. Perfilieva suggests the possibility of reverse influence $[11$, p. 200]. The adjoining of the western vestibule close to the windows is the result of restoration [17].

Dating to the end of the 10th century is confirmed by the study of the building solutions of the temple by the method of X-ray phase analysis.

The considered temples are distinguished by the unity of the planning solution, constructive scheme, and spatial composition. In both cases, a hierarchy of volumes is clearly built: the dome on a high drum - the arms of the cross - the apses - the corner compartments - the central part of the narthex - the lateral parts of the narthex - the narthex. Unfortunately, it is not possible to compare in detail the structures of the ceilings of the temples and the decor of the drums, since the crowning part in the temple of Simon the Canaanite is the result of works from the second half of the 19th century. As noted by K.N. Afanasyev, V.V. Pishchulina, the external dimensions and the size of the dome square [3.3a] are the same. In both temples, the axes of the side vestibules are displaced relative to the entrances, there are lunettes above the architraves of the doorways, however, the 
architraves of the Zelenchuk temple are simpler, while in the temple of Simon the Canaanite there is a Greek inscription and an image of a cross. However, along with similar elements, there are also differences. Thus, the masonry of the Anakopia temple is made of small blocks of hewn limestone, faced with large slabs of stone, and the masonry of Zelenchuksky is made of hewn stone using the above-described method, with binding the corners with larger stones; plinth is present in the masonry. Various forms of apses horseshoe-shaped from the inside, with a pentahedral outside central in the first and semicircular in the second. At the same time, Zelenchuksky has a synthronon and a solea. The shape of the pillars is also different: in Anakopia they are cross-shaped, in Zelenchuksky they are close to a square in cross-section. The narthex of the Zelenchuk temple is wider and has pilasters on the eastern wall; it opens into the main space with three openings, while in the Anakopia temple - with one. Finally, there are niches in the side vestibules of the Zelenchuk temples, while there are none in Anakopia.

\section{Conclusion}

The identified similarities and differences confirm the indisputable participation of Abkhaz craftsmen in the construction of the Northern Zelenchuk temple, the involvement of local masons who used regional traditions in the construction and indicate the chronological proximity of the two monuments, which is proved by the results of X-ray phase analysis of solutions.

The study was supported by a grant from the Russian Foundation for Basic Research 19-012$00402 \backslash 21$

\section{References}

1. Sh. R. Azatyan, Portals in the monumental architecture of Armenia IV -XIV centuries. (Sovetakan grokh, Yerevan, 1987)

2. Z.V. Anchabadze, History and culture of ancient Abkhazia (Nauka, Moscow, 1964)

3. K.N. Afanasyev, New materials on the archeology of the Central Caucasus, Ordzhonikidze: "Iriston", 105-119 (1986)

4. A.S. Bashkirov, Archaeological research in Abkhazia in the summer of 1925 (Abkhazian Scientific society News. Issue IV. Sukhum, 1926)

5. D.V. Beletsky, A.Yu. Vinogradov, Nizhny Arkhyz and Sents - the most ancient temples in Russia (Indrik, M., 2011)

6. A.Yu. Vinogradov, D.V. Beletsky, Byzantine time book 72 (97), 203-216 (2013)

7. Yu.N. Voronov, In the world of architectural monuments of Abkhazia (Art, M., 1978)

8. V.A. Kuznetsov, Soviet Archeology 4, 141-149 (1964) 
9. V.A. Kuznetsov, Christianity in the North Caucasus until the 15 th century (Vladikavkaz, 2002)

10. V.P. Patchulia, At the edge of the golden fleece (Science, M., 1964)

11. L.A. Perfilieva, On the question of the Byzantine influence on the cult architecture of the North-Western Caucasus in the 10th -11 th centuries. (Alans: Western Europe and Byzantium, Vladikavkaz, 1992)

12. V.V. Pishchulina, Architecture in the history of Russian culture: Fractures of the eras. M.: URSS 6, 38 - 54 (2005)

13. V.V. Pishchulina, Christian temple architecture of the North Caucasus during the Middle Ages (Rostov-on-Don, 2006)

14. L.D. Rcheulishvili, Dome architecture of the 7th - 10th centuries in Abkhazia (Metsniereba, Tbilisi, 1988)

15. S.M. Sakania, G.V. Trebeleva, Late Antique and Medieval Temples of the NorthEastern Black Sea Region. Catalog. Volume 1. Western Abkhazia (Gagra, Gudauta, Sukhum regions). - Magnitogorsk: Magnitogorsk Printing House, 2019. - 201 p.

16. L.G. Khrushkova, Lykhny: a medieval palace complex in Abkhazia (M., 1990)

17. D.K. Chachkhalia, Three-porch composition of the temples of medieval Abkhazia and its influence on the architectonics of the monuments of Alania, Russia and Trebizond (AQUA-Abaza, M., 2016) 